Article

\title{
Soil and Water Conservation in Rainfed Vineyards with Common Sainfoin and Spontaneous Vegetation under Different Ground Conditions
}

\author{
Nahed Ben-Salem ${ }^{1}$, Sara Álvarez ${ }^{1,2}$ (D) and Manuel López-Vicente ${ }^{1, * \text { (D) }}$ \\ 1 Department of Soil and Water, Experimental Station of Aula Dei, EEAD-CSIC. Avda. Montañana 1005, \\ 50059 Zaragoza, Spain; nahed.bensalem@yahoo.com (N.B.-S.); alvmarsa@itacyl.es (S.Á.) \\ 2 Unit of Woody and Horticultural Crops, Technological Agriculture Institute of Castilla y León, ITACyL. \\ Ctra. Burgos Km. 118, 47071 Valladolid, Spain \\ * Correspondence: mvicente@eead.csic.es or mlopezvicente@gmail.com; Tel.: +34-976-71-61-24
}

Received: 2 July 2018; Accepted: 6 August 2018; Published: 9 August 2018

\begin{abstract}
Soil erosion seriously affects vineyards. In this study, the influence of two vegetation covers on topsoil moisture and the effect of different physiographic conditions on runoff and sediment yields were evaluated in a rainfed vineyard formed by four fields (NE Spain) during 15 months. One field had spontaneous vegetation in the inter-row areas, and three fields had a cover crop of common sainfoin. Moisture conditions were dry and stable in the vineyards' rows, wet and very variable in the inter-row areas and wet and very stable in the corridors. Topsoil moisture in the areas with common sainfoin was much higher than in the rows $(62-70 \%)$, whereas this difference was lower with spontaneous vegetation ( $40 \%$ ). Two runoff and sediment traps (STs) were installed in two ephemeral gullies, and 26 time-integrated surveys (TIS) were done. The mean runoff yields were 9.8 and 13.5 $\mathrm{L} \mathrm{TIS}^{-1}$ in ST2 and ST3. Rainfall depth $(12 \mathrm{~mm})$ and erosivity $\left(5.2 \mathrm{MJ} \mathrm{mm} \mathrm{ha}^{-1} \mathrm{~h}^{-1}\right)$ thresholds for runoff initiation were assessed. The mean turbidity was 333 (ST2) and 19 (ST3) $\mathrm{g} \mathrm{L}^{-1}$. Changes in the canopy covers (grapevines and vegetation covers), topography and rainfall parameters explained the runoff and sediment dynamics.
\end{abstract}

Keywords: cover crop; spontaneous vegetation; vineyard; topsoil water content; soil erosion; runoff coefficient; sediment trap; temporal stability; Mediterranean region

\section{Introduction}

Vineyards are amongst the most important fruit crops in the world, covering 7.5 million ha and producing 75.8 million of tons of grapes and 267 million $\mathrm{hL}$ of wine [1]. The European Union reaches $39 \%$ of the world grape production, with Spain being its third largest wine producer, including 975,000 ha of vineyards [2], which is the largest vineyard extension in the European Union and the world. In spite of its economical pertinence, long-term vineyard sustainability may be threatened due to land degradation and/or mismanagement, linked with runoff, soil and nutrient losses, which complicate the suitable crop growth and yield [3,4].

Vineyards and orchards are part of the most exposed agricultural systems deteriorated by soil erosion processes [5], which generate higher runoff rates and sediment losses in Europe than arable land, scrubland, grassland and forest. Only bare soils had higher soil erosion rates. These differences are especially marked in the landscapes of the Mediterranean Basin [6,7]. Recently, Rodrigo-Comino [8] concluded in a review study that soil erosion rates in vineyards represent a serious threat to landscape sustainability. The analysis of data collected from runoff plots across Europe and the Mediterranean Basin illustrated that runoff coefficients in vineyards (ca. $8 \%$ ) were similar as those observed in cereal and fallow fields $(8.0 \%$ and $7.3 \%)$, although soil loss was much higher in vineyards $\left(10.8 \mathrm{Mg} \mathrm{ha}^{-1} \mathrm{y}^{-1}\right)$ 
than in arable and fallow land (6.5 and $\left.5.8 \mathrm{Mg} \mathrm{ha}^{-1} \mathrm{y}^{-1}\right)$ [9]. However, the mean standard deviation (sd) of the soil erosion rates in vineyards from the Mediterranean zone $\left(\mathrm{sd}=27.4 \mathrm{Mg} \mathrm{ha}^{-1} \mathrm{y}^{-1}\right)$ and the rest of Europe $\left(\mathrm{sd}=26.0 \mathrm{Mg} \mathrm{ha}^{-1} \mathrm{y}^{-1}\right)$ is very high, and thus, the spatial variability of soil loss in this crop is also high [5].

Erosion rates in Mediterranean vineyards are extensively variable, but achieve up to $16 \mathrm{Mg} \mathrm{ha}^{-1}$ $\mathrm{y}^{-1}$ in Sicily, Southern Italy [3], and between 1.8 (grass covered) and 20.7 (reduced tillage) $\mathrm{Mg} \mathrm{ha}^{-1} \mathrm{y}^{-1}$ in NW Italy [10]. In Barcelona province, NE Spain, Ramos and Martínez-Casasnovas [11] estimated an average rate of $10.9 \mathrm{Mg} \mathrm{ha}^{-1} \mathrm{y}^{-1}$ in levelled vineyards, whereas Bienes et al. [12] measured average rates between 0.4 and $1.8 \mathrm{Mg} \mathrm{ha}^{-1} \mathrm{y}^{-1}$ in Central Spain (Madrid and Cuenca) under conventional tillage and during a low rainfall erosivity period, and between 0.02 and $0.32 \mathrm{Mg} \mathrm{ha}^{-1} \mathrm{y}^{-1}$ with different vegetation covers (Brachypodium distachyon, spontaneous vegetation, rye and barley). In southern France, Gómez et al. [13] observed in three experimental sites over three years average soil loss rates between 4.5 and $90 \mathrm{Mg} \mathrm{ha}^{-1} \mathrm{y}^{-1}$ under conventional tillage and between 0.7 and $42.7 \mathrm{Mg} \mathrm{ha}^{-1} \mathrm{y}^{-1}$ with cover crops. In Israel, Pipan and Kokalj [14] observed increased soil erosion owing to the conversion of terraced vineyards into recent plantations in slopes without terraces. Such rates are superior to soil erosion under natural, non-cropped conditions, even for steep slopes (1.6 Mg ha ${ }^{-1} \mathrm{y}^{-1}$ in $63 \%$ slopes) [15] and over the tolerable or admissible soil losses that ensure land sustainability (ca. $1 \mathrm{Mg} \mathrm{ha}^{-1} \mathrm{y}^{-1}$ ) [16].

The main reasons for the elevated soil erosion rates in the Mediterranean vineyards are: (i) their traditional location on steep hillslopes; (ii) placing of the vineyard's rows parallel to the highest slope gradient to facilitate tillage and tractor traffic, which make runoff and erosion more intensive [17]; (iii) the semiarid and subhumid climatic conditions, with dry summers and intense rainfall events that trigger high runoff peaks, especially in spring and autumn [18]; and (iv) high soil erodibility conditions, as vineyards are mostly planted on shallow soils [7], hence with low structural stability of the soil aggregates [19]. Such degradation of soil quality may lead to severe problem for wine production as soil figures as a key component of the concept of "terroir" [20]. Therefore, protection of soils is an important issue in viticulture and necessary to promote sustainable agricultural systems.

Most winegrowers control weeds by means of tilling and/or herbicide applications owing to the observed competition between unplanted vegetation and grapevines for water and nutrients [21]. Nevertheless, not all studies indicated the expected regression in grape yields in vineyards with vegetation cover (VC) in the inter-rows [22,23], but similar or even higher yields were observed in vineyards with VC in the inter-rows [24,25]. In addition, some techniques usually adopted in vineyards' installation and management (e.g., intense tractor traffic throughout fixed paths) deteriorate soil structure and produce soil surface compaction [26]. In the literature, the benefits of VC in vineyards, fruit-tree orchards and reclaimed soils has been widely evaluated in a variety of soil and climate conditions throughout the world [13,27-29].

In Mediterranean vineyards, several studies have demonstrated the positive effects of VC on soil, nutrient and water conservation, such as in Italy [10,26,30,31], Spain [12,22,32-34] and France [13,35,36]. On average, VC reduces the total volume of runoff yield, offering an adequate protection against erosion in comparison with bare soil management [22,32]. Moreover, soil structure and functional soil properties improved through better aggregate stability and pore connectivity, higher values of field-saturated hydraulic conductivity appearing in the soils with VC than under conventional tillage (CT) [31]. Both the labile and stable fractions improve their soil organic carbon content with the use of groundcovers, particularly the labile fraction [34]. Another positive aspect of VC with respect to $\mathrm{CT}$ is that the cover plants are able to reduce the formation of plough pan, by virtue of a decrease in mechanized work, the growth of the root system and the improvement of the soil structure [30].

In the same agriculture context, the antecedent moisture condition or topsoil water content (TSWC) is a major factor influencing runoff generation during low- and medium-intensity storms $[37,38]$ and soil detachment at the first phases of an erosive event [39]. The study of Ramos and Martínez-Casasnovas [40] confirmed the relationship between the volumetric soil water content 
of the soil profile and the vegetative development of the vineyard and its yield. On the other hand, annual runoff and soil losses in woody crops are strongly conditioned by few precipitation events of high rainfall intensity and/or depth [41,42]. Under low frequency-high magnitude rainfall events, straw residues and VC can reduce soil erosion and runoff rates in fruit-tree orchards [43].

A better comprehension of the hydrological response of the soil to rainfall events, taking into account the monthly variability of the soil surface conditions and the canopy covers, could be helpful to promote soil management decisions in vineyards, in order to increase TSWC and to reduce runoff yield and soil erosion. However, we did not find any study comparing TSWC dynamics in vineyards with VC of common sainfoin and spontaneous vegetation, nor the influence of different ground conditions on runoff and sediment yield in a vineyard with common sainfoin in the inter-row areas. Hence, the main objective of this study is to evaluate the processes of soil and water conservation in a rainfed vineyard with different VC and ground conditions. We achieve this goal by means of: (i) measuring the TSWC in 48 control points in the three vineyards' compartments (rows, inter-row areas and corridors) during a 15-month test period; (ii) collecting runoff and sediment samples from two runoff collectors (sediment traps (ST)) installed in two ephemeral gullies with different ground conditions between their upslope contributing areas; and (iii) analyzing the spatial and temporal dynamics of TSWC, runoff and sediment yields, taking into account the changes in the rainfall parameters (depth, intensity and erosivity) and ground cover (surface and canopy) conditions. The results of this study will be of interest for planning sustainable management practices in vineyards and other woody crops.

\section{Materials and Methods}

\subsection{Study Area}

The study area is a rainfed vineyard located in the Ebro River Basin (NE Spain; $42^{\circ} 02^{\prime} 04^{\prime \prime} \mathrm{N} ; 0^{\circ}$ $04^{\prime} 13^{\prime \prime}$ E) (Figure 1a). This vineyard includes four fields that are located in the lower part of "Los Oncenos" sub-catchment, within the Vero River catchment, near Barbastro town (Huesca province) (Figure 1b). This site is located on a rolling landscape with a mean slope gradient of $9.8 \%$ and elevation ranges from $447-468 \mathrm{~m}$ a.s.l. The four commercial vineyards (Fábregas Cellar, a winery with Certificate of Origin: Somontano) are cultivated with the Spanish variety Grenache (Vitis vinifera L. cv. Grenache), three fields with red grapes (planted in 2008; named VY1, VY2 and VY3) and one field with white grapes (planted in 2007; VY4), without any irrigation. The vineyard plantation is arranged in 147 straight lines (espalier system). Soil in the grapevine lines (row hereafter) remain between 8 and $23 \mathrm{~cm}, 13 \mathrm{~cm}$ on average, raised related to the soil in the inter-row area, due to the tillage practices carried out by the farmer.

The inter-row areas of the vineyards are managed with a mixture of plant species as vegetation crop (VC): (i) spontaneous vegetation in VY4; and (ii) plantation of common sainfoin (Onobrychis viciifolia) with spontaneous vegetation in VY1, VY2 and VY3. Spontaneous vegetation also protects the soil in the corridors between the four vineyards. The maintenance of the VC includes one mowing pass in spring, usually in May, to avoid water and nutrient competition between the VC and the grapevines. Most pruning remains stay in the same place after this practice, and thus, the soil cover factor (percentage of the soil surface covered with vegetation) keeps high all over the year. The farmer only used herbicides to control weeds in the rows. During this study, grape harvest was done in September (more details in [33]).

Soils are Haplic Regosols (calcaric; RGca) in the upper part of VY4 and Luvic Calcisols (CLl) in the lower part of VY4 and in VY1, VY2 and VY3 [44]. In a recent study, López-Vicente and Álvarez [33] collected 144 soil samples in 48 sampling points in the four vineyards and estimated the bulk density (BD), rock content (rock fragments (RF); fragments with a minimum diameter higher than $2 \mathrm{~mm}$ ) and texture of the soil. The average ( \pm standard deviation) $\mathrm{BD}$ and $\mathrm{RF}$ in the four vineyards was $1.482( \pm 0.205) \mathrm{g} \mathrm{cm}^{-3}$ and $15.8 \%( \pm 7.7 \%)$, respectively (more details in Table 1$)$. The effective volume of the soil to store water ( $\mathrm{Vol}_{\mathrm{eff}}$; associated with the fine fraction of the soil) was $90.7 \%( \pm 4.7 \%)$. 
Soil texture was sandy loam, loam, silt loam and loamy sand in $38 \%, 29 \%, 28 \%$ and $4 \%$ of the soil samples, with some differences between the rows, the inter-row areas and the corridors, and between the four fields.

Table 1. Bulk density (BD), rock fragments (RF), effective volume $\left(\mathrm{Vol}_{\mathrm{eff}}\right)$ and soil texture in the three vineyards' compartments and the four fields.

\begin{tabular}{cccccccc}
\hline $\begin{array}{c}\text { Vineyard } \\
\text { Compartment }\end{array}$ & $\begin{array}{c}\text { BD } \\
\mathbf{g ~ c m}^{-3}\end{array}$ & $\begin{array}{c}\text { RF } \\
\mathbf{\%}\end{array}$ & $\begin{array}{c}\text { Vol }_{\text {eff }} \\
\mathbf{\%}\end{array}$ & SdL & L & StL & LS \\
\hline The 4 vineyards (VYs) & 1.482 & 15.8 & 90.7 & 38 & 29 & 28 & 4 \\
VYs, rows & 1.343 & 16.7 & 90.9 & 40 & 28 & 32 & ND \\
VYs, inter-row areas & 1.582 & 14.7 & 90.8 & 37 & 31 & 24 & 8 \\
VYs, corridors & 1.582 & 18.0 & 88.6 & 33 & 22 & 44 & ND \\
VY1 & 1.704 & 15.0 & 89.9 & 67 & 11 & 6 & 17 \\
VY2 & 1.406 & 8.5 & 95.3 & 11 & 56 & 33 & ND \\
VY3 & 1.429 & 15.5 & 91.2 & 24 & 27 & 42 & 6 \\
VY4 & 1.456 & 17.8 & 89.7 & 45 & 29 & 24 & 2 \\
\hline
\end{tabular}

SdL: sandy loam; L: loam; StL: silt loam; LS: loamy sand; ND: no data.

The climate is continental Mediterranean, with an average annual precipitation, $R$, of $446( \pm 14 \%)$ mm $\mathrm{y}^{-1}$ during the period September' 2009-August' 2017, mainly concentrated in two rainy seasons, in spring and autumn (source data: 'Oficina del Regante' of the Regional Government of Aragon and 'CHEbro' (Ebro River Basin water authorities)). The summer is dry with occasional thunderstorms, and snowfall events are scarce in winter. The mean annual temperature was $14.1^{\circ} \mathrm{C}$, and potential evapotranspiration, $E T_{0}$, was $1225 \mathrm{~mm}_{\text {year }}{ }^{-1}$. The mean annual rainfall intensity was $3.1( \pm 22 \%) \mathrm{mm}$ $\mathrm{h}^{-1}$. The average number of annual rainfall events was 98 with 6 and 11 events per year of medium $(8<R<12 \mathrm{~mm})$ and high $(R>12 \mathrm{~mm})$ rainfall depth. This site is characterized by (long-lasting) rainfall events of low rainfall intensity $\left(I_{30}\right)$ between December and March (mean $I_{30}=1.9 \mathrm{~mm} \mathrm{~h}^{-1}$ ) and short and high intensity events between May and November (mean $I_{30}=4.1 \mathrm{~mm} \mathrm{~h}^{-1}$ ) [45]. The highest peaks of $I_{30}$ are usually recorded in October (ca. $6 \mathrm{~mm} \mathrm{~h}^{-1}$ ). Consequently, different hydrological response of the soils is expected over the year: saturation-excess runoff areas (occurring when the soil becomes saturated) may happen during the winter (although ponding areas were not observed), whereas infiltration excess runoff (when the rainfall intensity is higher than the infiltration rate) is the predominant overland flow generation process, which is the common runoff generation mechanism in Mediterranean soils.

Various ephemeral gullies affect the soils in VY1, VY3 and VY4, two cereal fields and the olive orchard in "Los Oncenos" sub-catchment [46]. Sediment delivery processes are intense, bringing the formation of four depositional areas (alluvial fans) at the foot of the vineyards VY1 and VY4 $\left(1480 \mathrm{~m}^{2}\right)$, one cereal field and of the commercial olive grove (Figure 1b). These processes have launched the development of continuous flow path lines, breaking the topographic sills of the rows in some sections (Figure 1c). 


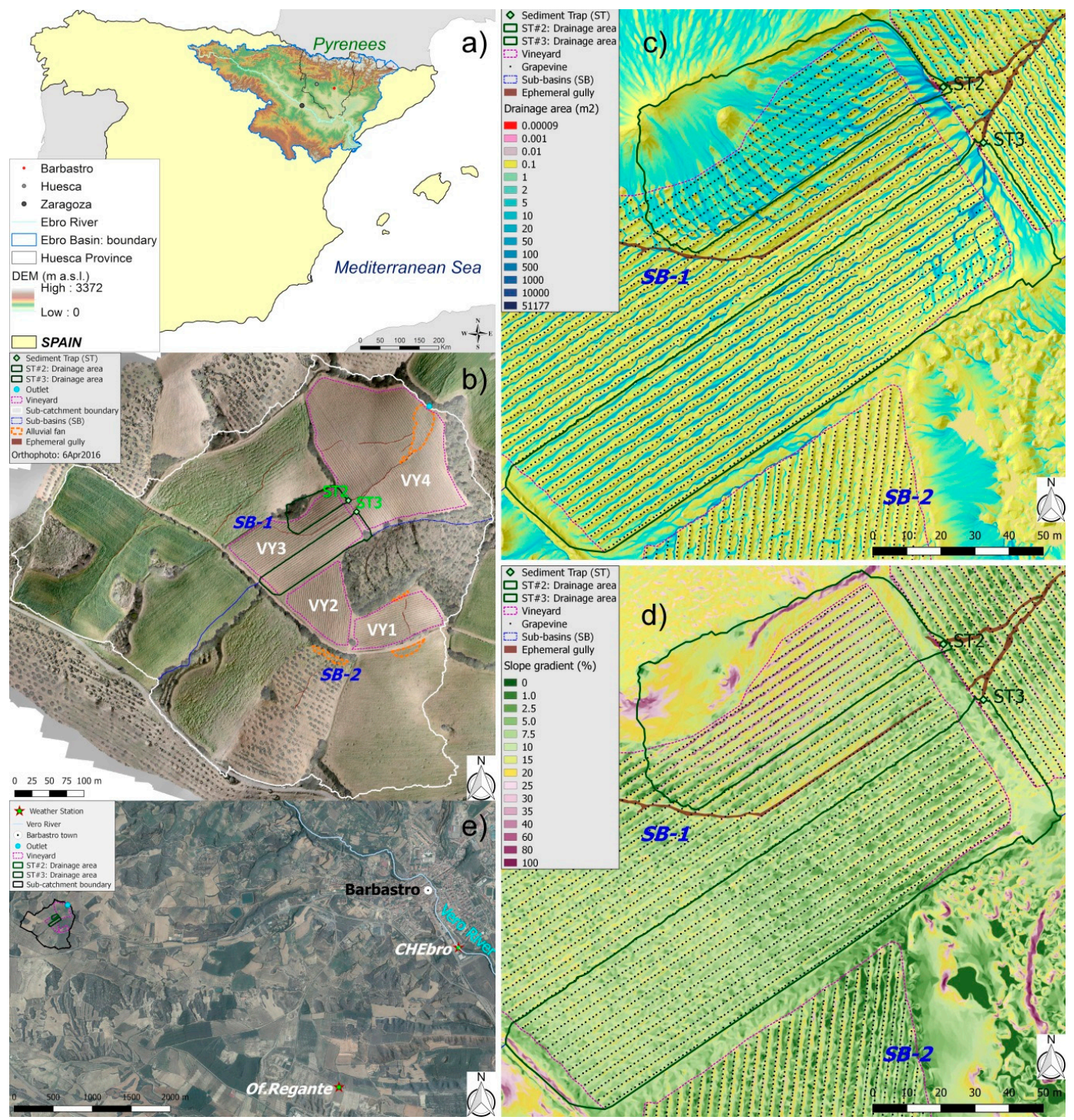

Figure 1. Location of the study area in Huesca Province, NE Spain (a); orthophoto and boundary of "Los Oncenos" sub-catchment and the location of the two sediment traps (b); drainage area (c) and slope gradient (d) of the two sediment traps; location of the two weather stations used in this study (e).

\subsection{Rainfall Data and Topsoil Water Content}

Rainfall data were obtained from two weather stations (WSs) located 4.2 and $5.2 \mathrm{~km}$ east of the study site (Figure 1e). The "CHEbro" and "Of.Regante" WSs recorded precipitation every 15 and $30 \mathrm{~min}$, respectively. As slight differences were observed between the records of the two WSs, a synthetic weather station (Syn-WS) was created by using the data of both WSs. We firstly equalized the temporal resolution of both records by calculating the values of precipitation every $30 \mathrm{~min}$ at the "CHEbro" WS. Then, we calculated the mean value of precipitation between the two WSs at each 30-min interval and assigned this value to the Syn-WS. As the two WSs are located at similar elevations and distances from the study area, we assumed that the same rainfall events affected the three sites. In similar Mediterranean landscapes without a WS within the study site, López-Vicente and Navas [47] and López-Vicente et al. [48] generated synthetic WSs to study and model runoff and soil erosion processes. De Oliveira et al. [49] also used synthetic rainfall series to estimate rainfall erosivity in Brazil. We used the guide of the RUSLE model that establishes a period of six hours with a rainfall volume lower than $1.27 \mathrm{~mm}$ to distinguish between two different rainfall events [50]. This model identifies 
an erosive rainfall event when the total rainfall depth is higher than $12 \mathrm{~mm}$ and/or $I_{30}$ is higher than $6 \mathrm{~mm}$ in $15 \mathrm{~min}$. We used these criteria and fractions of this value to calculate the number of very low $\left(R<4 \mathrm{~mm}\right.$ event $\left.^{-1}\right)$, low $\left(4<R<8 \mathrm{~mm}\right.$ event $\left.^{-1}\right)$, medium $\left(8<R<12 \mathrm{~mm} \mathrm{event}^{-1}\right)$ and high erosivity $\left(R>12 \mathrm{~mm}^{\text {event }}{ }^{-1}\right.$ or $R>6 \mathrm{~mm}$ in $\left.15 \mathrm{~min}\right)$ rainfall events in the Syn-WS. Rainfall depth $(R$; $\mathrm{mm})$, maximum intensity in $30 \mathrm{~min}\left(I_{30} ; \mathrm{mm} \mathrm{h}^{-1}\right)$ and rainfall erosivity $\left(E I_{30} ; \mathrm{MJ} \mathrm{mm} \mathrm{ha}{ }^{-1} \mathrm{~h}^{-1}\right)$ were calculated at event, monthly and average scales.

The topsoil water content (TSWC, $\theta_{0} ; \%$ vol.) was measured in the field in 48 points of undisturbed soils, and three measurements of $\theta_{0}$ were effectuated at each point (144 measurements per survey; Figure 2a). One survey was done every 30 days during the 15-month test period (February 2017-April 2018). Each survey was carried out in the same days of the month, between Days 15 and 19. The frequency-domain probe Delta-T SM150T (accuracy $\pm 3 \%$ ) was used (Figure 2b). This device has two rods, which are initiated in the soil up to a 51-mm depth. Measurements were stable regarding salinity.

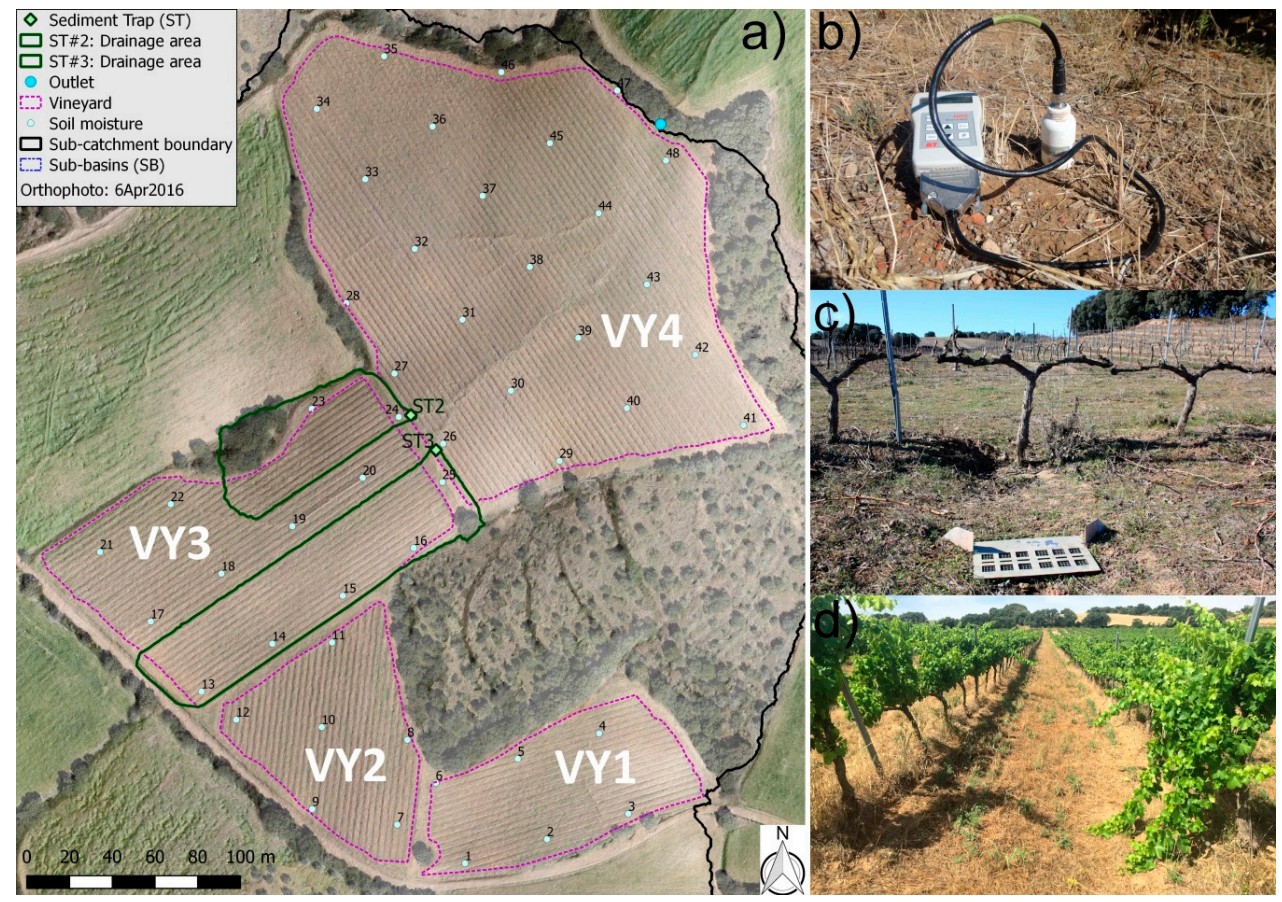

Figure 2. Location of the topsoil water content (TSWC) measurement points in the four vineyards of "Los Oncenos" sub-catchment (a). Photos of the device to measure TSWC (b), of the sediment trap \#2 with the upslope contributing area (c) (taken on 12 February 2018) and of the cover crop in the contributing area of the sediment trap \#3 after the mowing pass in late May 2017 (d) (taken on 27 June 2017).

A portable device was selected to assess topsoil moisture rather than installing permanent devices (sensors, data loggers and batteries) due to the elevated number of measurement points and therefore the high economic cost. The distance between each measurement point within each vineyard was $40 \mathrm{~m}$ including the three compartments: rows, inter-row areas and corridors. Each survey was carried out in less than $6 \mathrm{~h}$ in order to minimize the temporal changes during each survey. There were no rainfall events recorded during each survey, nor during the four previous days. Thus, measured values are representative of the monthly edaphoclimatic conditions.

\subsection{Runoff and Sediment Traps and Surface Cover Changes}

Two sediment traps (ST2 and ST3) were established in the first inter-row of VY4 downwards the corridor that separates VY3 and VY4 (Figure 1c). Each ST was located in the course of an ephemeral gully and installed below the soil surface to avoid any disturbance with the tractor traffic. The two 
STs played the role of collectors of runoff and sediment generated during the different rainfall-runoff events. Each trap had two boxes: one box was buried and permanently remained in the field; the other one was located inside the first box. A metal grid with holes $(4 \times 4 \mathrm{~mm})$ was located on the top of the smaller box to avoid the entrance of animals and rocks. Finally, a metal cap with big holes $(7 \times 7 \mathrm{~cm})$ was used to close the trap with screws and nuts (Figure 2c). Each trap was designed to hold a maximum volume of $32.2 \mathrm{~L}$ (460 mm length $\times 200 \mathrm{~mm}$ width $\times 350 \mathrm{~mm}$ depth). Both STs were installed in December 2016 and tested in January 2017. From 1 February 2017 on, both STs were ready to collect samples. After each heavy rainfall event of after several low- or medium-intensity rainfall events, the runoff and sediment samples were collected in a time-integrated field survey (TIS). Every TIS covered the period (in days) between the latest and the new field survey. After sample collection, the internal boxes were replaced with clean boxes. Then, the total runoff with sediments of each trap was weighted and sediment separated by decantation. The wet sediment was dried in an oven at $60{ }^{\circ} \mathrm{C}$, and the dry sediment was weighted. Finally, the total runoff (Q; L TIS ${ }^{-1}$ ) and sediment yield (SY; $g$ TIS ${ }^{-1}$ ) were calculated for each ST and TIS.

The contributing areas (CAs) of the ST2 and ST3 were 3286 and $6214 \mathrm{~m}^{2}$, with a mean slope gradient of $17.0 \%$ and $9.2 \%$, respectively (Figure 1c,d) (Table 2) (more details about the overland flow patterns in [46]). Concerning the vegetation cover, the soil surface of the CA of the ST2 had less vegetation with an average percentage of bare soil of $18.4 \%$, whereas the CA of the ST3 only had $10.6 \%$ of the soil surface without vegetation (Figure $2 c, d$ ). Several pictures of the canopy covers of the two CAs were taken every month from the same points and looking in the same direction. An overall estimation of the bare soil areas was done for each picture with Corel PaintShop ${ }^{\circledR}$ Pro X7 (64-bit) software. Significant changes in the surface cover were observed over the twelve months of the year due to the phenology of the grapevines, the cover crop, the spontaneous vegetation and the tillage practices (e.g., grape harvest and mowing pass) (Figure 3). In a recent study, López-Vicente and Álvarez [46] calculated several topographic parameters in "Los Oncenos" sub-catchment (Table 2). Soil roughness and flow and sediment connectivity (water-mediated transfer of soil and sediments within a hydrological unit) were higher in CA-ST2 than in CA-ST3, indicating active processes of sediment delivery. Moreover, CA-ST2 was closer to a concave topography, whereas CA-ST3 indicated a general convex surface. All the topographic information used in this study was derived from a digital elevation model (DEM) at $0.2 \mathrm{~m}$ of cell size [46].

Table 2. Physiographic characteristics of the upslope contributing area of the two sediment traps.

\begin{tabular}{ccccccc}
\hline $\begin{array}{c}\text { Sediment Trap } \\
\text { Number }\end{array}$ & $\begin{array}{c}\text { A } \\
\mathbf{m}^{2}\end{array}$ & $\begin{array}{c}\text { S (mean } \pm \text { sd) } \\
\mathbf{\%}\end{array}$ & $\begin{array}{c}\text { Average Bare Soil } \\
\mathbf{\%}\end{array}$ & $\begin{array}{c}\text { SR } \\
\mathbf{m m}\end{array}$ & $\begin{array}{c}\mathbf{C I}^{*} \\
\mathbf{\%}\end{array}$ & $\begin{array}{c}\text { IC * } \\
\text { Mean (max) }\end{array}$ \\
\hline ST2 & 3286 & $17.0 \pm 9.5$ & 18.4 & 21.5 & -0.143 & $-6.394(-4.695)$ \\
ST3 & 6214 & $9.2 \pm 5.0$ & 10.6 & 11.6 & -0.668 & $-6.821(-4.818)$ \\
\hline
\end{tabular}

A: total area; S: slope gradient; SR: soil roughness; CI: convergence index; IC: index of runoff and sediment connectivity; ${ }^{*}$ values from [46]. 


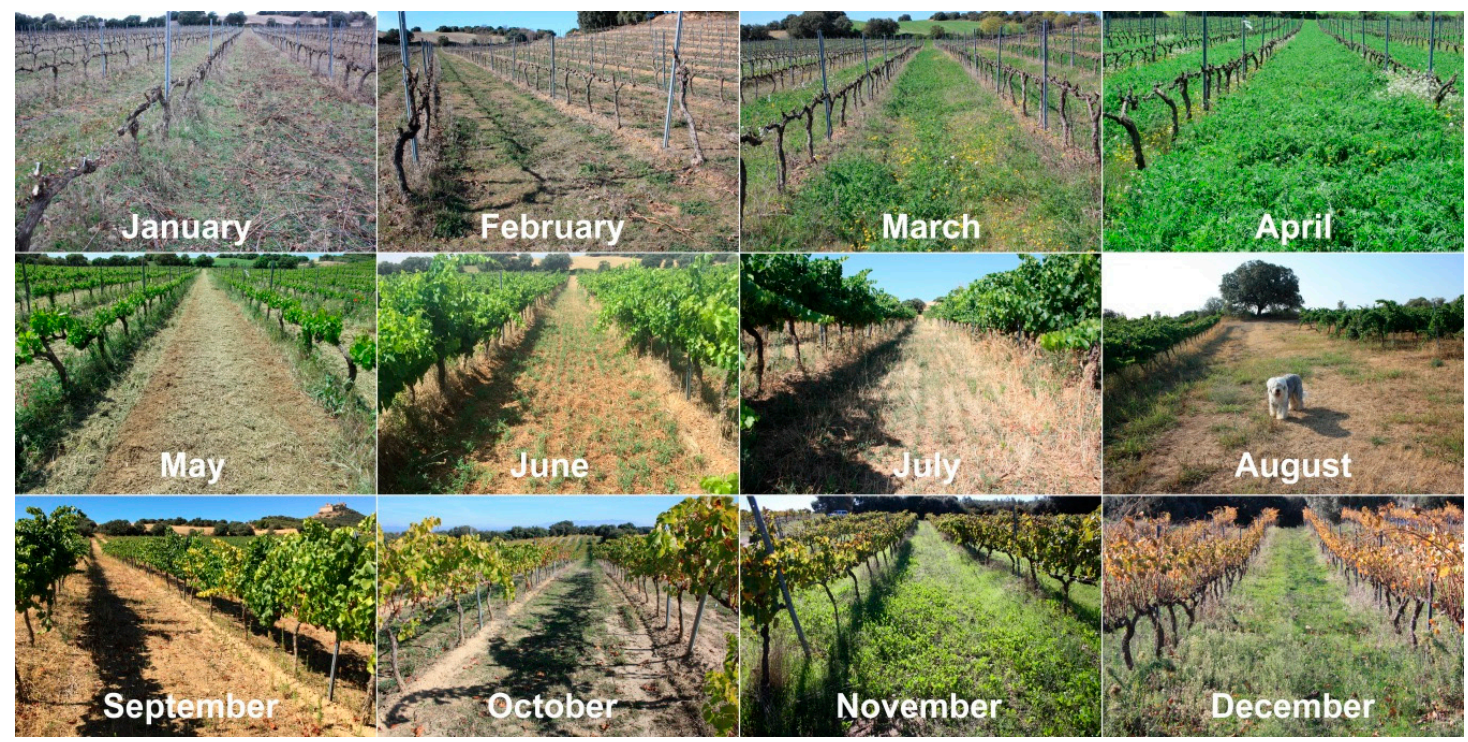

Figure 3. Temporal changes in the canopy cover of the grapevines and the cover crop of common sainfoin over the twelve months of the year.

\subsection{Statistical Analysis and Metrics}

The spatial pattern of TSWC was calculated for each survey by means of the mean relative difference at each location ' $i$ ', $M R D_{i T}$ :

$$
\begin{gathered}
M R D_{i T}=\frac{1}{N_{T}} \sum_{m=1}^{m=N_{T}} \delta_{i m} \\
\delta_{i m}=\frac{\theta_{0 i m}-\overline{\theta_{0 m}}}{\overline{\theta_{0 m}}}
\end{gathered}
$$

where $N_{T}$ is the number of observation times (15 months) and $\delta_{i m}$ is the relative difference between the average value of TSWC at each measurement point ' $i$ ', $\theta_{0 \mathrm{im}}$, and the mean value of TSWC in the four vineyards at each month ' $m$ ', $\overline{\theta_{0 m}}$ [51]. The temporal stability analysis of these differences was done calculating the standard deviation of the set $\delta_{i, m=1}, \delta_{i, m=2}, \ldots, \delta_{i, m=T}$ of relative differences at the location ' $i$ ' over the test period:

$$
S D R D_{i T}=\sqrt{\frac{1}{N_{T}-1} \sum_{m=1}^{m=N_{T}}\left(\delta_{i m}-M R D_{i T}\right)^{2}}
$$

The value of $S D R D_{i T}$ serves as one of the measures of the temporal stability $[28,33,51,52]$ by comparing its magnitude to the spatial variability of $M R D_{i T}$. The sensitivity analysis was done for the vineyards' compartments (rows, inter-row areas and corridors) of each field and for the whole study area. Finally, correlations between the rainfall parameters and those of runoff $(\mathrm{Q})$ and sediment yields (SY) were calculated with SigmaPlot ${ }^{\circledR}$ 13.0.

\section{Results}

\subsection{Synthetic Weather Station and Topsoil Moisture}

Small differences of rainfall data appeared between the two WSs owing to the short distance between them, only $2.4 \mathrm{~km}$, and the common spatial variability of precipitation (Table 3). During the test period, the maximum rainfall depths were 69.0 and $56.4 \mathrm{~mm}$ for the "CHEbro" and "Of.Regante", 
respectively; and the total rainfall was 749 and $632 \mathrm{~mm}$. However, the total number of rainfall events $(R e)$ clearly changed between the two WS, with 50 and 135 Re registered by the "CHEbro" and "Of.Regante" WSs, respectively. The dominance of very low erosivity events was observed in the two WS (64\% and 70\% of the total $R e$ ). The second dominant type of rainfall events was that of high erosivity adding $18 \%$ and $15 \%$ of the total Re in the "CHEbro" and "Of.Regante" WSs. The low and medium erosivity $R e$ added the remaining $18 \%$ and $15 \%$. The mean and maximum values of $I_{30}$ were similar between the two WSs, and we only observed differences in the median values of $I_{30}$. The mean and total values of rainfall erosivity $\left(E I_{30}\right)$ showed moderate differences between the two WS, with lower values $(-18 \%$ and $-38 \%)$ in the "CHEbro" WS. These differences supported the necessity of generating a synthetic weather station to study the processes of the hydrological response of the soil (TSWC, runoff and soil erosion) in "Los Oncenos" sub-catchment.

Table 3. Rainfall data and erosivity at the two weather stations during the 15-month test period (TP).

\begin{tabular}{|c|c|c|c|c|}
\hline Parameter & Type/Value & Of.Regante & CHEbro & $\Delta(\%)$ \\
\hline $\begin{array}{l}\text { Rainfall events } \\
\qquad(R e) \\
(n)\end{array}$ & $\begin{array}{c}\text { Total } \\
\text { Very low erosivity, } n(\%) \\
\text { Low erosivity, } n(\%) \\
\text { Medium erosivity, } n(\%) \\
\text { High erosivity, } n(\%)\end{array}$ & $\begin{array}{c}135 \\
95(70 \%) \\
9(7 \%) \\
11(8 \%) \\
20(15 \%)\end{array}$ & $\begin{array}{c}50 \\
32(64 \%) \\
6(12 \%) \\
3(6 \%) \\
9(18 \%)\end{array}$ & $\begin{array}{l}-63 \\
-66 \\
-33 \\
-73 \\
-55\end{array}$ \\
\hline $\begin{array}{c}\text { Rainfall depth } \\
(R) \\
(\mathrm{mm})\end{array}$ & $\begin{array}{c}\text { Minimum } \\
\text { Mean } \\
\text { Median } \\
\text { Maximum } \\
\text { CV }(\%) \\
\text { Total } \\
\end{array}$ & $\begin{array}{c}0.2 \\
5.5 \\
0.6 \\
69.0 \\
187 \% \\
748.7\end{array}$ & $\begin{array}{c}0.2 \\
6.2 \\
2.0 \\
56.4 \\
156 \% \\
631.6\end{array}$ & $\begin{array}{c}0 \\
13 \\
2.33 \\
-18 \\
-17 \\
-16 \\
\end{array}$ \\
\hline $\begin{array}{l}\text { Rainfall intensity } \\
\qquad\left(I_{30}\right) \\
\left(\mathrm{mm} \mathrm{h}^{-1}\right)\end{array}$ & $\begin{array}{l}\text { Minimum } \\
\text { Mean } \\
\text { Median } \\
\text { Maximum } \\
\text { CV }(\%)\end{array}$ & $\begin{array}{c}0.4 \\
3.0 \\
0.8 \\
24.0 \\
157 \%\end{array}$ & $\begin{array}{c}0.4 \\
3.5 \\
1.6 \\
25.2 \\
126 \%\end{array}$ & $\begin{array}{c}0 \\
17 \\
100 \\
5 \\
-20\end{array}$ \\
\hline $\begin{array}{l}\text { Rainfall erosivity } \\
\left(E I_{30}\right) \\
\left(\mathrm{MJ} \mathrm{mm} \mathrm{ha} \mathrm{mm}^{-1} \mathrm{~h}^{-1}\right. \\
\left.\mathrm{TP}^{-1}\right)\end{array}$ & $\begin{array}{l}\text { Minimum } \\
\text { Mean } \\
\text { Median } \\
\text { Maximum } \\
\text { CV }(\%) \\
\text { Total }\end{array}$ & $\begin{array}{c}0.006 \\
7.09 \\
0.04 \\
187.01 \\
315 \% \\
957.48\end{array}$ & $\begin{array}{c}0.007 \\
5.81 \\
0.28 \\
117.22 \\
260 \% \\
592.18\end{array}$ & $\begin{array}{c}17 \\
-18 \\
600 \\
-37 \\
-17 \\
-38\end{array}$ \\
\hline
\end{tabular}

The total rainfall depth in the synthetic weather station (Syn-WS) was $690.2 \mathrm{~mm}$ during the 15-month test period (TP), and the total rainfall erosivity was $735.3 \mathrm{MJ} \mathrm{mm} \mathrm{ha}{ }^{-1} \mathrm{~h}^{-1} \mathrm{TP}^{-1}$ (Figure 4). The highest rainfall depths were calculated in April 2018 (117 mm), March 2017 (108 mm) and March $2018(86 \mathrm{~mm})$ and the lowest $\left(R<12 \mathrm{~mm} \mathrm{month}^{-1}\right)$ in August 2017, November 2017 and July 2017. However, the highest values of rainfall erosivity $\left(E I_{30}\right)$ were obtained in April 2018 (139 MJ mm ha ${ }^{-1} \mathrm{~h}^{-1}$ month $^{-1}$ ), March 2017 (112 MJ mm ha ${ }^{-1} \mathrm{~h}^{-1}$ month $^{-1}$ ) and October 2017 $\left(108 \mathrm{MJ} \mathrm{mm} \mathrm{ha}{ }^{-1} \mathrm{~h}^{-1} \mathrm{month}^{-1}\right)$. The highest mean values of rainfall intensity $\left(I_{30}\right)$ were estimated in November $2017\left(6.4 \mathrm{~mm} \mathrm{~h}^{-1}\right)$, October $2017\left(6.0 \mathrm{~mm} \mathrm{~h}^{-1}\right)$ and June $2017\left(5.2 \mathrm{~mm} \mathrm{~h}^{-1}\right)$ and the lowest $\left(I_{30}<1.2 \mathrm{~mm} \mathrm{~h}^{-1}\right)$ in August 2017 and in the period December 2017-February 2018. The number of monthly medium and high erosivity events (MH-Ee) ranged from $0-5$, with none MH-Ee during five months, whereas four months had three or more MH-Ee. The correlation between the values of $E I_{30}$ and those of $R\left(R^{2}=0.6525\right)$ and $I_{30}\left(R^{2}=0.5498\right)$ were high and with the number of MH-Ee was weak $\left(R^{2}=0.2245\right)$. The correlation between $R$ and $I_{30}$ was very weak $\left(R^{2}=0.0853\right)$, and non-correlation appeared between $I_{30}$ and number of MH-Ee. However, a good correlation was found between $R$ and the number of MH-Ee $\left(R^{2}=0.5775\right)$. 


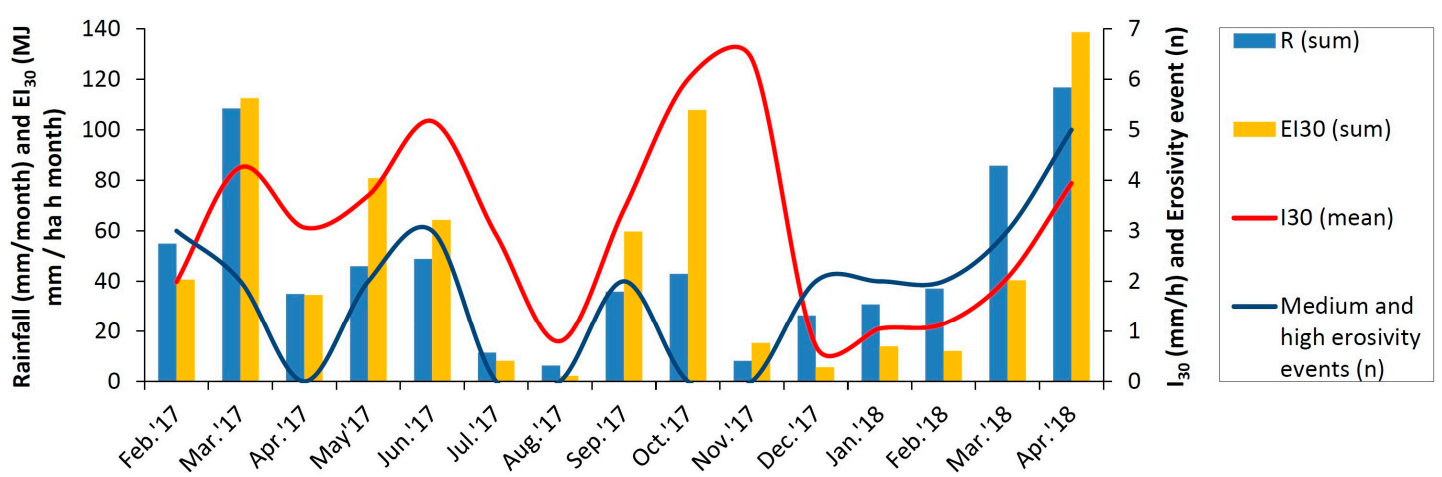

Figure 4. Monthly values of rainfall depth $(R)$, maximum intensity $\left(I_{30}\right)$ and erosivity $\left(E I_{30}\right)$ and the number of medium and high rainfall erosivity events $(n)$ in the synthetic weather station (Syn-WS).

The values of TSWC clearly varied over the test period, with high average values $\left(\theta_{0}>20 \%\right.$ vol.) in February 2017 and during the period December 2017-April 2018. The driest average soil conditions $\left(\theta_{0}<6.5 \%\right.$ vol.) were observed in June and July 2017 (Figure 5). This temporal pattern was identical in the three vineyards' compartments. During the 15-month test period, the average TSWC in the four fields was $15.9 \%$ vol. (Table 4 ). TSWC was higher in the inter-row areas (average $\theta_{0}=18.5 \%$ vol.) and the corridors (average $\theta_{0}=19.4 \%$ vol.) than in the rows (average $\theta_{0}=12.1 \%$ vol.). This spatial pattern was constant in the four fields regardless of the type of plant cover. However, these differences were much higher in the three fields (VY1, VY2 and VY3) with common sainfoin as cover crop (CC) (differences between $62 \%$ and $70 \%$ ) than in the VY4 with spontaneous vegetation as CC. In the last case, the difference was $40 \%$ on average during the test period. The corridors had slightly wetter conditions than the inter-row areas for 11 months, although the differences between these two compartments were not significant. As expected, a moderate positive correlation was found between the observed monthly values of TSWC and those of the calculated rainfall depth (Pearson's $r=0.439$ ). However, we found a similar, but negative correlation between TSWC and $I_{30}$ (Pearson's $\mathrm{r}=-0.458$ ).

Concerning the relative differences of TSWC at each measurement point $\left(\delta_{i t}\right)$, the minimum differences (negative values) reached the lowest values (closest to zero; between -0.40 and -0.43 ) during the wettest months $\left(\theta_{0}>20 \%\right.$ vol.) and the highest values (far from zero; between -0.66 and -0.73 ) during the driest months $\left(\theta_{0}<9 \%\right.$ vol.) $\left(R^{2}=0.7716\right)$. In the same way, the maximum relative differences (positive values) reached the lowest values during the wettest months and the highest values during the driest months $\left(R^{2}=0.8222\right)$ (Supplementary Figure S1). Thus, the spatial variability of TSWC increased during the dry months, and more homogeneous conditions appeared during the wet months.

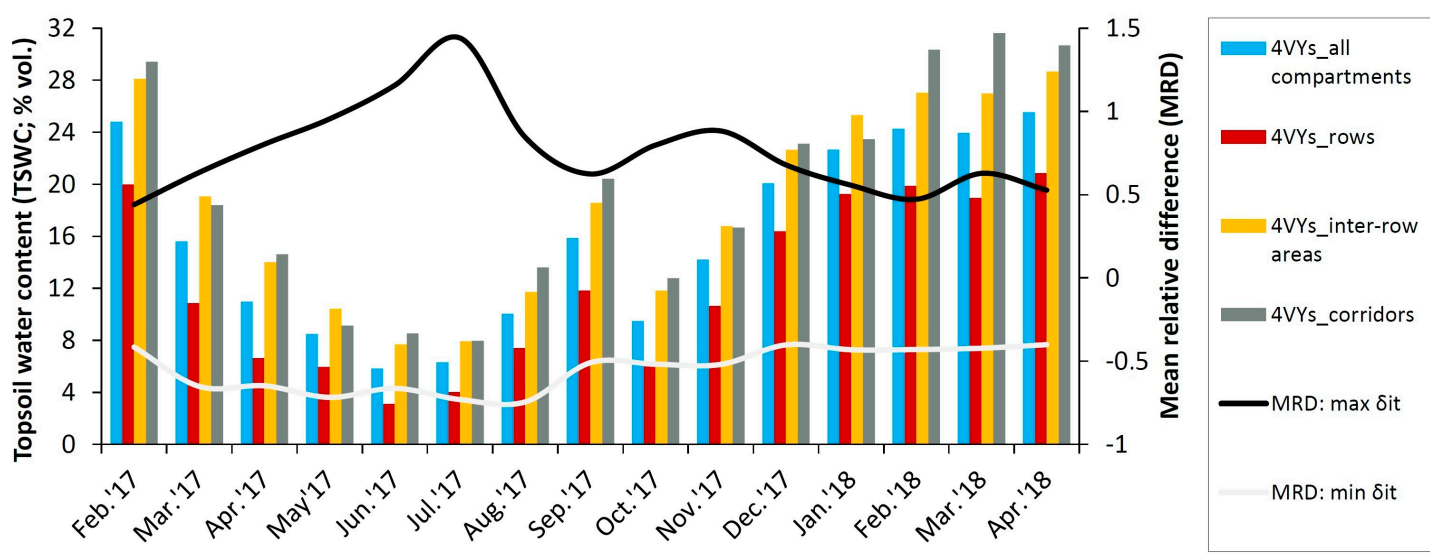

Figure 5. Evolution of the monthly values of TSWC in the three vineyards' compartments of the four fields (4VYs) and of the mean minimum and maximum relative differences (MRD). 
Table 4. Topsoil water content (TSWC) in the different vineyards and compartments over the test period. The mean relative difference (MRD), standard deviation of the MRD (SDRD) and the coefficients of variation $(\mathrm{CV})$ are included.

\begin{tabular}{cccccccc}
\hline $\begin{array}{c}\text { Vineyard } \\
\text { Compartment }\end{array}$ & VC & \multicolumn{2}{c}{ TSWC (\% vol.) } & MRD & SDRD & CV & Conditions \\
\hline Mean & CV (\%) & & & (\%) & - \\
The 4 vineyards (VYs) & - & 15.9 & 33 & 0 & 0.212 & - & Dry and stable \\
VYs, rows & BS & 12.1 & 25 & -0.271 & 0.188 & 69 & Wet and very variable \\
VYs, inter-row areas & CC and SP & 18.5 & 23 & 0.186 & 0.239 & 129 & Wet and very stable \\
VYs, corridors & SP & 19.4 & 18 & 0.239 & 0.149 & 62 & Dry and variable \\
VY1, rows & BS & 12.1 & 22 & -0.258 & 0.228 & 89 & Very wet and stable \\
VY1, inter-row areas & CC & 20.7 & 25 & 0.343 & 0.271 & 79 & Dry and variable \\
VY2, rows & BS & 12.9 & 18 & -0.197 & 0.193 & 98 & Very wet and very stable \\
VY2, inter-row areas & CC & 21.6 & 11 & 0.381 & 0.245 & 64 & Very dry and very stable \\
VY3, rows & BS & 11.7 & 18 & -0.305 & 0.179 & 59 & Wet and variable \\
VY3, inter-row areas & CC & 18.9 & 18 & 0.194 & 0.194 & 100 & Very dry and very stable \\
VY4, rows & BS & 12.1 & 23 & -0.284 & 0.179 & 63 & Slightly wet and very variable \\
VY4, inter-row areas & SP & 16.9 & 21 & 0.093 & 0.257 & 276 & and \\
\hline
\end{tabular}

VC: vegetation cover; SP: spontaneous vegetation; BS: bare soil; CC: cover crop of common sainfoin.

The temporal stability of the spatial patterns was analyzed in the three vineyards' compartments and at the field scale, as well (Table 4). Dry and very dry conditions corresponded to negative MRD values lower than the 33rd (Q33; MRD $=-0.188)$ and 25th $(\mathrm{Q} 25 ; \mathrm{MRD}=-0.270)$ percentiles, respectively; wet and very wet conditions corresponded to positive MRD values higher than Q66 $(\mathrm{MRD}=0.162)$ and $\mathrm{Q75}(\mathrm{MRD}=0.240)$, respectively. The coefficients of variation $(\mathrm{CV})$ were used to assess the temporal stability of the spatial patterns: very stable $(\mathrm{CV}<65 \%)$, stable $(65 \%<\mathrm{CV}<80 \%)$, variable $(80 \%<\mathrm{CV}<100 \%)$ and very variable $(\mathrm{CV}>100 \%)$ conditions. The most stable conditions appeared in the corridors and vineyards' rows, whereas higher temporal variability was observed in the inter-row areas. This temporal dynamic was not constant in the four fields. VY1 and VY2 presented similar conditions between them, although VY3 had very dry and very stable conditions in the rows. On average, the vineyards' rows had dry and stable conditions in the three fields with common sainfoin as cover crop, and very dry and very stable conditions in the field with spontaneous vegetation. The soil moisture conditions in the inter-row areas in the three fields with common sainfoin were wet and very wet and stable, whereas in VY4, they were slightly wet and very variable. Thus, the different plant covers affected the spatial and temporal dynamics of TSWC in the vineyards' compartments.

\subsection{Runoff and Sediment Yield}

From the total of 26 time-integrated surveys (TIS) we collected runoff and sediment samples in 21 TIS (Table 5). During the five TIS without runoff generation the accumulated rainfall depth, $\sum R$, was lower than $12 \mathrm{~mm}$ and the accumulated rainfall erosivity, $\sum E I_{30}$, was lower than $5.2 \mathrm{MJ} \mathrm{mm} \mathrm{ha}{ }^{-1}$ $\mathrm{h}^{-1}$ TIS $^{-1}$. There were only two TIS with runoff generation (Q) with $\sum R<12 \mathrm{~mm}$ and one TIS with $\mathrm{Q}$ $>0 \mathrm{~L}$ with $\sum E I_{30}<5.2 \mathrm{MJ} \mathrm{mm} \mathrm{ha}{ }^{-1} \mathrm{~h}^{-1} \mathrm{TIS}^{-1}$; during these events, the maximum rainfall intensity $\left(I_{30}\right)$ was higher than $3 \mathrm{~mm} \mathrm{~h}^{-1}$ in the first case, and $\sum R$ was ca. $14 \mathrm{~mm}$ in the second case. The $\sum R$ threshold to reach $\mathrm{Q}>20 \mathrm{~L} \mathrm{TIS}^{-1}$ was ca. $18 \mathrm{~mm}$, and $\mathrm{Q}>30 \mathrm{~L} \mathrm{TIS}^{-1}$ was only found with $\sum R>45 \mathrm{~mm}$. A positive correlation was found between $\sum R$ and $Q$ in ST2 (Pearson's $r=0.546 ; p<0.01$ ) and ST3 (Pearson's $r=0.595 ; p<0.01$ ) (Table 6). A weak correlation was found between $Q$ and $\sum E I_{30}$ and no correlation between $Q$ and $I_{30}$. Between TIS Numbers 4 and 26, the mean Q was 9.8 and 12.9 L TIS $^{-1}$ in ST2 and ST3, and the total Q was 224.7 and 297.3 L TIS $^{-1}$ in ST2 and ST3. The three first TIS were excluded in this comparison owing to the malfunctioning of ST2 during this period. The correlation between $\mathrm{Q}$ values from the two STs was high (Pearson's $\mathrm{r}=0.700 ; p<0.001$ ), although we observed runoff generation in ST2 in TIS\#6 without runoff yield in ST3, and conversely, we collected runoff in ST3 in TIS\#7 and \#10 without runoff yield in ST2. During TIS\#6 and \#7, Q $<1 \mathrm{~L} \mathrm{TIS}^{-1}$ while Q $>20 \mathrm{~L}$ TIS $^{-1}$ in ST3 in TIS\#10. 
Table 5. Accumulated rainfall depth $\left(\sum R\right)$ and erosivity $\left(\sum E I_{30}\right)$, number of rainfall events $(R e)$ and mean rainfall intensity $\left(\overline{I_{30}}\right)$ calculated with the synthetic weather station and runoff $(Q)$ and sediment (SY) yields observed in the two sediment traps (ST) at each time-integrated survey (TIS) during the 15-month test period.

\begin{tabular}{|c|c|c|c|c|c|c|c|c|}
\hline TIS & & $\sum R$ & $\operatorname{Re}$ & $\overline{I_{30}}$ & $\sum E I_{30}$ & ST & Q & SY \\
\hline Date & $\#$ & $\mathrm{~mm}$ & $n$ & $\mathrm{~mm} \mathrm{~h}^{-1}$ & $\begin{array}{c}\text { MJ mm ha } \mathrm{mIS}^{-1} \mathrm{~h}^{-1} \\
\text { TI }^{-1}\end{array}$ & $\#$ & $\mathrm{~L} \mathrm{TIS}^{-1}$ & $\mathrm{~g} \mathrm{TIS}^{-1}$ \\
\hline 07 February 2017 & 1 & 24.3 & 3 & 4.0 & 10.3 & $\begin{array}{l}\text { ST2 } \\
\text { ST3 }\end{array}$ & $\begin{array}{c}\text { MF } \\
26.488\end{array}$ & $\begin{array}{l}\text { ND } \\
16.1\end{array}$ \\
\hline 16 February 2017 & 2 & 30.1 & 3 & 3.6 & 30.4 & $\begin{array}{l}\text { ST2 } \\
\text { ST3 }\end{array}$ & $\begin{array}{c}\text { MF } \\
23.824\end{array}$ & $\begin{array}{l}\text { ND } \\
39.8\end{array}$ \\
\hline 08 March 2017 & 3 & 34.1 & 8 & 1.5 & 43.1 & $\begin{array}{l}\text { ST2 } \\
\text { ST3 }\end{array}$ & $\begin{array}{c}\text { MF } \\
3.678\end{array}$ & $\begin{array}{l}\text { ND } \\
22.6\end{array}$ \\
\hline 28 March 2017 & 4 & 70.3 & 4 & 4.0 & 68.1 & $\begin{array}{l}\text { ST2 * } \\
\text { ST3 * }\end{array}$ & $\begin{array}{l}30.195 \\
30.010\end{array}$ & $\begin{array}{c}30.9 \\
124.6\end{array}$ \\
\hline 17 April 2017 & 5 & 11.7 & 2 & 4.0 & 5.1 & $\begin{array}{l}\text { ST2 } \\
\text { ST3 }\end{array}$ & $\begin{array}{l}0 \\
0\end{array}$ & $\begin{array}{l}0 \\
0\end{array}$ \\
\hline 04 May 2017 & 6 & 23.3 & 7 & 2.4 & 29.4 & $\begin{array}{l}\text { ST2 } \\
\text { ST3 }\end{array}$ & $\begin{array}{c}0.720 \\
0\end{array}$ & $\begin{array}{c}3.4 \\
0\end{array}$ \\
\hline 17 May 2017 & 7 & 31.9 & 6 & 3.6 & 68.8 & $\begin{array}{l}\text { ST2 } \\
\text { ST3 }\end{array}$ & $\begin{array}{c}0 \\
0.930\end{array}$ & $\begin{array}{c}0 \\
2.9\end{array}$ \\
\hline 06 June 2017 & 8 & 39.9 & 5 & 4.8 & 27.9 & $\begin{array}{l}\text { ST2 } \\
\text { ST3 }\end{array}$ & $\begin{array}{l}1.500 \\
4.787\end{array}$ & $\begin{array}{l}2.3 \\
7.1\end{array}$ \\
\hline 16 June 2017 & 9 & 2.8 & 1 & 3.0 & 0.8 & $\begin{array}{l}\text { ST2 } \\
\text { ST3 }\end{array}$ & $\begin{array}{l}0 \\
0\end{array}$ & $\begin{array}{l}0 \\
0\end{array}$ \\
\hline 27 June 2017 & 10 & 19.4 & 1 & 16.2 & 47.6 & $\begin{array}{l}\text { ST2 } \\
\text { ST3 }\end{array}$ & $\begin{array}{c}\text { MF } \\
21.128\end{array}$ & $\begin{array}{l}\text { ND } \\
38.9\end{array}$ \\
\hline 10 July 2017 & 11 & 10.8 & 4 & 3.3 & 8.0 & $\begin{array}{l}\text { ST2 } \\
\text { ST3 }\end{array}$ & $\begin{array}{l}0.383 \\
0.462\end{array}$ & $\begin{array}{l}1.7 \\
1.4\end{array}$ \\
\hline 29 August 2017 & 12 & 7.6 & 9 & 1.0 & 2.4 & $\begin{array}{l}\text { ST2 } \\
\text { ST3 }\end{array}$ & $\begin{array}{l}0 \\
0\end{array}$ & $\begin{array}{l}0 \\
0\end{array}$ \\
\hline 19 September 2017 & 13 & 16.7 & 6 & 1.5 & 9.0 & $\begin{array}{l}\text { ST2 } \\
\text { ST3 }\end{array}$ & $\begin{array}{l}0.645 \\
0.206\end{array}$ & $\begin{array}{l}27.8 \\
15.2\end{array}$ \\
\hline 26 September 2017 & 14 & 18.1 & 1 & 17.8 & 50.7 & $\begin{array}{l}\text { ST2 ** } \\
\text { ST3 }\end{array}$ & $\begin{array}{l}9.942 \\
7.071\end{array}$ & $\begin{array}{c}32,825.8 \\
1,821.6\end{array}$ \\
\hline 17 October 2017 & 15 & 1.3 & 3 & 0.4 & 0.1 & $\begin{array}{l}\text { ST2 } \\
\text { ST3 }\end{array}$ & $\begin{array}{l}0 \\
0\end{array}$ & $\begin{array}{l}0 \\
0\end{array}$ \\
\hline 25 October 2017 & 16 & 42.9 & 2 & 8.9 & 107.9 & $\begin{array}{l}\text { ST2 ** } \\
\text { ST3 ** }\end{array}$ & $\begin{array}{c}8.546 \\
26.513\end{array}$ & $\begin{array}{c}41,260.2 \\
2,778.4\end{array}$ \\
\hline 17 November 2017 & 17 & 8.0 & 1 & 12.6 & 15.3 & $\begin{array}{l}\text { ST2 } \\
\text { ST3 }\end{array}$ & $\begin{array}{c}23.156 \\
8.252\end{array}$ & $\begin{array}{l}281.4 \\
911.6\end{array}$ \\
\hline 20 December 2017 & 18 & 13.8 & 8 & 0.8 & 2.9 & $\begin{array}{l}\text { ST2 } \\
\text { ST3 }\end{array}$ & $\begin{array}{l}1.012 \\
0.276\end{array}$ & $\begin{array}{l}2.2 \\
0.4\end{array}$ \\
\hline 18 January 2018 & 19 & 28.6 & 19 & 0.8 & 12.1 & $\begin{array}{l}\text { ST2 } \\
\text { ST3 }\end{array}$ & $\begin{array}{l}28.396 \\
24.612\end{array}$ & $\begin{array}{l}60.5 \\
38.1\end{array}$ \\
\hline 12 February 2018 & 20 & 42.4 & 9 & 0.8 & 11.5 & $\begin{array}{c}\text { ST2 } \\
\text { ST3 * }\end{array}$ & $\begin{array}{c}2.287 \\
28.766\end{array}$ & $\begin{array}{c}0.8 \\
44.6\end{array}$ \\
\hline 19 February 2018 & 21 & 9.5 & 4 & 5.8 & 5.0 & $\begin{array}{l}\text { ST2 } \\
\text { ST3 }\end{array}$ & $\begin{array}{l}0 \\
0\end{array}$ & $\begin{array}{l}0 \\
0\end{array}$ \\
\hline 07 March 2018 & 22 & 45.4 & 5 & 2.0 & 18.1 & $\begin{array}{l}\text { ST2* } \\
\text { ST3 * }\end{array}$ & $\begin{array}{l}30.711 \\
30.237\end{array}$ & $\begin{array}{l}13.3 \\
18.8\end{array}$ \\
\hline
\end{tabular}


Table 5. Cont.

\begin{tabular}{|c|c|c|c|c|c|c|c|c|}
\hline TIS & & $\sum R$ & $R e$ & $\overline{I_{30}}$ & $\sum E I_{30}$ & ST & $\mathbf{Q}$ & SY \\
\hline Date & $\#$ & $\mathbf{m m}$ & $n$ & $\mathrm{~mm} \mathrm{~h}^{-1}$ & $\begin{array}{c}\text { MJ mm ha }{ }^{-1} h^{-1} \\
\text { TIS }^{-1}\end{array}$ & $\#$ & L TIS $^{-1}$ & $\mathrm{~g} \mathrm{TIS}^{-1}$ \\
\hline 19 March 2018 & 23 & 23.3 & 10 & 2.3 & 16.8 & $\begin{array}{l}\text { ST2 } \\
\text { ST3 }\end{array}$ & $\begin{array}{l}28.466 \\
28.380\end{array}$ & $\begin{array}{l}84.5 \\
40.7\end{array}$ \\
\hline 05 April 2018 & 24 & 17.7 & 6 & 1.3 & 5.6 & $\begin{array}{c}\text { ST2 } \\
\text { ST3 * }\end{array}$ & $\begin{array}{c}0.861 \\
28.900\end{array}$ & $\begin{array}{c}4.1 \\
42.0\end{array}$ \\
\hline 18 April 2018 & 25 & 93.8 & 8 & 4.4 & 101.1 & $\begin{array}{l}\text { ST2 * } \\
\text { ST3 * }\end{array}$ & $\begin{array}{l}28.834 \\
29.034\end{array}$ & $\begin{array}{l}59.2 \\
30.2\end{array}$ \\
\hline 30 April 2018 & 26 & 22.4 & 4 & 4.9 & 37.6 & $\begin{array}{l}\text { ST2* } \\
\text { ST3* }\end{array}$ & $\begin{array}{l}29.023 \\
27.702\end{array}$ & $\begin{array}{c}94.3 \\
572.7\end{array}$ \\
\hline
\end{tabular}

MF: malfunctioning; *: ST completely full of runoff; **: ST completely full of sediments.

Table 6. Pearson's correlation coefficients between observed runoff (Q) and sediment (SY) yields at each sediment trap (ST) during the 26 time-integrated surveys (TIS) and the corresponding values of rainfall depth $(R)$, maximum intensity $\left(I_{30}\right)$ and erosivity $\left(E I_{30}\right)$ calculated from the synthetic weather station. Significant level between brackets: coefficients in bold are significant at the 0.01 level.

\begin{tabular}{ccccc}
\hline Sediment Trap & Observed Values & $\boldsymbol{R}$ & $\boldsymbol{I}_{\mathbf{3 0}}$ & $\boldsymbol{E I}_{\mathbf{3 0}}$ \\
\hline \multirow{2}{*}{ ST2 } & $\mathrm{Q}$ & $\mathbf{0 . 5 4 6}(0.0070)$ & $0.042(0.8482)$ & $0.329(0.1255)$ \\
& $\mathrm{SY}$ & $0.082(0.7105)$ & $\mathbf{0 . 5 3 6}(0.0083)$ & $\mathbf{0 . 5 3 7}(0.0082)$ \\
$\mathrm{ST} 3$ & $\mathrm{Q}$ & $\mathbf{0 . 5 9 5}(0.0014)$ & $0.040(0.8453)$ & $0.365(0.0669)$ \\
& $\mathrm{SY}$ & $0.056(0.7863)$ & $\mathbf{0 . 5 9 4}(0.0014)$ & $\mathbf{0 . 5 3 3}(0.0050)$ \\
\hline
\end{tabular}

The sediment yield (SY) clearly changed between ST2 and ST3. Between TIS\#4 and \#26, the mean SY was 3250 and $282 \mathrm{~g}^{\text {TIS }}{ }^{-1}$ in ST2 and ST3, the median 3.4 and $18.8 \mathrm{~g} \mathrm{TIS}^{-1}$, the maximum 41,260 and $2778 \mathrm{~g} \mathrm{TIS}^{-1}$ and the total 74,752 and $6489 \mathrm{~g}^{\text {TIS }}{ }^{-1}$ (Table 5). The number of TIS when SY $<50 \mathrm{~g} \mathrm{TIS}^{-1}$ was nine and 12 in ST2 and ST3, whereas SY $>100 \mathrm{~g} \mathrm{TIS}^{-1}$ in three and five TISs in ST2 and ST3 (Supplementary Figure S2). We only observed high (SY > $1000 \mathrm{~g}^{\text {TIS }}{ }^{-1}$ ) and very high (SY > 30,000 $\mathrm{g} \mathrm{TIS}^{-1}$ ) soil erosion dynamics in TIS\#14 and \#16. The total SY collected during these TISs represented $99 \%$ and $70 \%$ of the total SY recorded in ST2 and ST3 during the whole test period, respectively.

A positive correlation was found between $I_{30}$ and SY in ST2 (Pearson's $r=0.536 ; p<0.01$ ) and ST3 (Pearson's $\mathrm{r}=0.594 ; p<0.01$ ), as well as between $\sum E I_{30}$ and SY in both STs (Table 6). No correlation was found between $\sum R$ and SY. The observed SY in ST2 correlated very well with that of ST3 (Pearson's $r=0.946 ; p<0.0001$ ), although a very low correlation was found between the values of $\mathrm{Q}$ and SY during the test period (Pearson's $\mathrm{r}=0.072$ ). Runoff turbidity $(\mathrm{QT})$ or sediment concentration was calculated considering the total runoff volume and sediment weight observed during the test period, obtaining a QT value of 333 and $19 \mathrm{~g} \mathrm{~L}^{-1}$ in T2 and T3.

\section{Discussion and Further Research}

\subsection{Soil Moisture Dynamics}

The contrasted climatic conditions in the study area, with two humid periods, one in spring and one in autumn, a dry and hot summer and a mile and relatively dry winter, explained the observed temporal evolution of TSWC over the year in the four vineyards. In Mediterranean regions, changes in the rainfall inter-seasonal distribution have been observed and evaluated in vineyards, indicating potential soil moisture stress during the critical growth stages of the grapevines [53]. 
Thus, monitoring soil moisture in the different vineyards' compartments over the year appears as a necessary task to propose best management practices for commercial vineyards.

On average, TSWC in the vineyards' inter-row areas was $52 \%$ higher than in the rows. These results can be explained by the conservation role played by the plant covers and agreed with the results obtained by López-Vicente and Álvarez [33] in a previous study in "Los Oncenos" sub-catchment after analyzing an older database of TSWC in several land uses. The observed differences in the effectiveness of water conservation between the cover crop (CC) of common sainfoin and the plant cover of spontaneous vegetation (SP) may be explained by the differences in plant density, much higher in the CC than in the SP. In olive orchards in southern Spain, López-Vicente et al. [28] also found different runoff coefficients in runoff crops with homogeneous and heterogeneous plant covers. The wet and stable soil moisture conditions observed in the corridors may be explained by: (i) the occasional tractor traffic that compacts the topsoil, reducing evaporation; (ii) the lack of grapevines in this compartment that clearly reduces the water consumption; (iii) the presence of SP that favored water infiltration; and (iv) the higher content of silt and the lower content of sand in the soils of this compartment in comparison with the rows and inter-row areas (see Table 1). Furthermore, high values of soil moisture were found in the unpaved trails in "Los Oncenos" sub-catchment in the previously cited study [33]. In the same context, Biddoccu et al. [10] found an increase in the TSWC in vineyards due to the soil compaction by tractor traffic that sealed the topsoil surface.

The elevated temporal variability of TSWC observed in the vineyards' inter-row areas can be explained by the significant changes in the surface cover factor over the year (Figure 3). Very low soil protection took place during the summer and at the beginning of autumn owing to the tillage practices done by the farmer at the end of May and the adverse climatic conditions during the summer for the growth of the plant covers. At the end of autumn, the percentage of the soil surface cover started increasing and reached the maximum values in April and in the first part of May (almost $100 \%$ ). The adopted soil management for the plant covers has strong impacts on the spatio-temporal variations of the soil surface characteristics (soil cover, topsoil structure and soil crusting) and on the soil hydrological properties and processes, which handle the partition of rainfall between runoff and infiltration at the field-scale [54]. Thus, different tillage practices of the vegetation covers may be considered in further research studies in vineyards and other woody crops. Besides, inter-annual TSWC dynamics in all land uses of "Los Oncenos" sub-catchment will be analyzed considering the influence of the main soil physical (e.g., infiltration, soil water retention curve) and chemical (carbon and nutrients) properties.

\subsection{Hydrological Response of the Soil}

The accumulated rainfall threshold, from estimated data, observed in this study (ca. $12 \mathrm{~mm}$ ) was higher than the rainfall threshold (between 4.6 and $8.5 \mathrm{~mm}$ ) observed by Rodrigo-Comino et al. [55] in sloping vineyards in southeastern Spain. This difference was explained by the soil surface conditions of both study sites: the cover crop of common sainfoin in our study area and totally bare soil conditions in the inter-row areas of Rodrigo-Comino et al.'s [55] study site. The higher mean and total runoff yields, $32 \%$ higher, observed in ST3 in comparison with ST2 were explained by the large upslope contributing area (CA) of ST3 that is $89 \%$ larger than the CA of ST2. On the other hand, the higher slope gradient (85\% higher) and percentage of bare soil over the year (74\% higher) of CA-ST2 in comparison with CA-ST3 explained the much higher mean and total (1052\% higher) sediment yields observed in ST2 in spite of it lower CA. The lack of correlation between the observed values of Q and SY at each ST during the test period was explained by the non-linearity relationship between runoff, soil erosion and sediment delivery. Smets et al. [56] also found considerable differences between the runoff and sediment yields during laboratory experiments with simulated rainfall $(60 \mathrm{~min})$ on a silt loam cultivated topsoil. Although CAs were calculated using an accurate DEM at a 0.2-m cell size, the topographic thresholds that delineate the divides are elevated between 1.8 and $12.4 \mathrm{~cm}$, and the estimated CAs depend on the spatial resolution of the DEM (see details about fractal geometry in López-Vicente and 
Álvarez [46]). Thus, we did not calculate the specific values of runoff $\left(\mathrm{L} \mathrm{m}^{-2} \mathrm{TIS}^{-1}\right)$ and sediment $\left(\mathrm{g} \mathrm{m}^{-2} \mathrm{TIS}^{-1}\right.$ ) yields because the actual CAs of each ST may vary during the low, medium, high and very high rainfall erosivity events that generate different runoff depths. Further research with closed runoff plots will allow reducing these problems. The highest values of $\mathrm{Q}$ and SY, that silted the ST, may be explained by larger effective CAs that were activated during the most intense rainfall-runoff events. Although we collected all runoff and sediment stored in the STs, part of the Q and SY could not be registered during these events. To correct this problem, we planned to install a set of larger STs at each ephemeral gully.

During the five TISs with the highest values of rainfall erosivity $\left(E I_{30}>50 \mathrm{MJ} \mathrm{mm} \mathrm{ha}{ }^{-1} \mathrm{~h}^{-1} \mathrm{TIS}^{-1}\right)$, we observed two contrasted hydrological and erosive responses of the soil. During TIS\#4 (March 2017) and \#25 (April 2018), runoff yields were very high, but SY was low, and during TIS\#7 (May 2017), both Q and SY were low. During these three events, the soil surface cover was very high owing to the growth of the cover crop (see Figure 3), and the average TSWC in the inter-row areas ranged between $10.4 \%$ and $28.7 \%$ vol. We assume that saturation-excess runoff was the predominant process. However, during TIS\#14 (September 2017) and \#16 (October 2017), the highest values of SY were observed. During these two months, the average TSWC in the inter-row areas ranged between $11.8 \%$ and $18.6 \%$ vol., and the soil surface cover was very low owing to the phenology of the cover crop, the dry and hot summer and the mowing pass done in late May 2017 on the cover crop. We assume that Hortonian runoff was the predominant process. The presence of plant debris (from the mowing pass) was only visible from June-August, and their soil conservation role was negligible in September and October. Thus, the evolution in the canopy cover of the grapevines and vegetation covers played an important role in the soil erosion dynamics of the two contributing areas. Biddoccu et al. [31] also observed in a vine-growing area in NW Italy that Hortonian runoff was predominant during the summer, whereas saturation-excess runoff occurred in autumn and winter. Besides, Biddoccu et al. [57] found in Italian vineyards high temporal variability of hydraulic conductivity and soil water content influenced by the soil surface conditions in relation to vineyard management, such as tilled inter-rows and grass cover. An accurate assessment of the evolution of the canopy cover over the year will be done in further research by using satellite (e.g., Sentinel-2) and detail field data. The mean sediment concentration in runoff $(\mathrm{QT})$ observed in the ST3 $\left(19 \mathrm{~g} \mathrm{~L}^{-1}\right)$ was similar to the concentration observed by Ramos and Martínez-Casasnovas [11] in levelled vineyards (mean slope ca. 9\%) in northeastern Spain with values ranging between 2.9 and $25.3 \mathrm{~g} \mathrm{~L}^{-1}$; whereas the mean QT observed in the ST2 $\left(333 \mathrm{~g} \mathrm{~L}^{-1}\right)$ reached much higher values due to the ground conditions (high slope gradient and percentage of bare soil) of its drainage area. The results of this study will be presented to the landowner and the staff of the Somontano Certificate of Origin of Wines as the first step in outreach and education for farmers and landowners in this region.

\section{Conclusions}

Topsoil water content (TSWC) varied during the test period, showing a good agreement with the evolution in the values of estimated total rainfall depth that presented contrasted conditions over the year. Dry conditions favored higher relative differences of TSWC along the vineyards, while more homogeneous spatial patterns appeared during the wet surveys. Concerning the different vineyards' compartments, the moistest conditions appeared in the inter-rows and corridors, with the presence of vegetation covers, whereas drier conditions appeared in the rows that had bare soil conditions. The cover crop of common sainfoin was more efficient to increase TSWC in the inter-row areas than spontaneous vegetation. Topsoil moisture conditions in the rows and corridors were stable, whereas the inter-rows presented higher temporal variability owing to the combined effect of the tillage practices and the climatic conditions that affected the vegetation covers' growth.

The thresholds of accumulated rainfall depth and/or rainfall erosivity that were necessary to generate runoff and thus net soil loss were identified for a rainfed vineyard with a cover crop of common sainfoin; higher values appearing than those observed in other vineyards under bare soil 
conditions. Besides, the thresholds to trigger high values of runoff and sediment yield were identified under different ground conditions. Satisfactory correlations were observed between the runoff yield and rainfall depth and between the sediment yield and rainfall intensity and erosivity.

The dynamics of runoff (Q) and sediment (SY) yields observed in the two sediment traps suggested that both contributing areas were activated during the same rainfall-runoff events, and the differences in $\mathrm{Q}$ and SY over the test period were explained by: (i) the differences in the ground conditions, such as the effective drainage area, the slope gradient and the percentage of soil surface cover; and (ii) the changes in the canopy cover (grapevines and vegetation covers) over the twelve months of the year that were associated with the plants' phenology and the tillage practices. The results of this study are of interest to improve the management and conservation of soil and water in rainfed Mediterranean vineyards, common sainfoin appearing as an efficient cover crop.

Supplementary Materials: The following are available online at http:/ /www.mdpi.com/2073-4441/10/8/1058/ s1, Figure S1: Correlation between the minimum (a) and maximum (b) relative differences $\left(\delta_{i t}\right)$ of TSWC during the 15-month test period, and the average value of monthly TSWC ( $\theta_{0}, \%$ vol. $)$ in the four vineyards, Figure S2: Evolution of the observed values of runoff (Q) and sediment (SY) yields in the two sediment traps (ST) during the 15-month test period. The average sediment concentration is also shown.

Author Contributions: M.L.-V. conceived of and designed the research. N.B.-S., S.Á. and M.L.-V. performed the field and laboratory work and processed the data. N.B.-S. and M.L.-V. analyzed the data and wrote the paper. M.L.-V. supervised the work and reviewed the final manuscript.

Funding: This research was funded by the project "Environmental and economic impact of soil loss (soil erosion footprint) in agro-ecosystems of the Ebro river basin: numerical modelling and scenario analysis (EroCostModel) (CGL2014-54877-JIN)" of the Spanish Ministry of Economy and Competitiveness. N.B.-S. was the beneficiary of a scholarship of the IAMZ-CIHEAM (Master of Science, second course, 2017-2018).

Acknowledgments: We especially thank Gonzalo Alcalde Fábregas (Fábregas Cellar, D.O. Somontano) for providing the vineyards where this research was done.

Conflicts of Interest: The authors declare no conflict of interest.

\section{References}

1. OIV-L'Organisation Internationale de la Vigne et du Vin. State of the Vitiviniculture World Market. 2017. Available online: http://www.oiv.int/public/medias/5287/oiv-noteconjmars2017-en.pdf (accessed on 6 February 2018).

2. OIV—L'Organisation Internationale de la Vigne et du Vin. World Vitiviniculture Situation, Statistical Report on World Vitiviniculture. 2017. Available online: http:/ / www.oiv.int/public/medias/5479/oiv-en-bilan2017.pdf (accessed on 6 February 2018).

3. Novara, A.; Pisciotta, A.; Minacapilli, M.; Maltese, A.; Capodici, F.; Cerdà, A.; Gristina, L. The impact of soil erosion on soil fertility and vine vigor. A mustidisciplinary approach based on field, laboratory and remote sensing approaches. Sci. Total Environ. 2018, 622-623, 474-480. [CrossRef] [PubMed]

4. Issaka, S.; Ashraf, M.A. Impact of soil erosion and degradation on water quality: A review. Geol. Ecol. Landsc. 2017, 1, 1-11. [CrossRef]

5. Cerdan, O.; Govers, G.; Le Bissonnais, Y.; Van Oost, K.; Poesen, J.; Saby, N.; Gobin, A.; Vacca, A.; Quinton, J.; Auerwald, K.; et al. Rates and spatial variations of soil erosion in Europe: A study based on erosion plot data. Geomorphology 2010, 122, 167-177. [CrossRef]

6. Tropeano, D. Soil-erosion on vineyards in the Tertiary Piedmontese Basin (Northwestern Italy): Studies on experimental areas. Catena Suppl. 1983, 3, 115-127.

7. García-Ruiz, J.M. The effects of land uses on soil erosion in Spain: A review. Catena 2010, 81, 1-11. [CrossRef]

8. Rodrigo-Comino, J. Five decades of soil erosion research in "terroir". The State-of-the-Art. Earth-Sci. Rev. 2018, 179, 436-447. [CrossRef]

9. Maetens, W.; Vamaercke, M.; Poesen, J.; Jankauskas, B.; Jankauskiene, G.; Ionita, I. Effects of land use on annual runoff and soil loss in Europe and the Mediterranean: A meta-analysis of plot data. Prog. Phys. Geogr. 2012, 36, 599-653. [CrossRef] 
10. Biddoccu, M.; Ferraris, S.; Opsi, F.; Cavallo, E. Long-term monitoring of soil management effects on runoff and soil erosion in sloping vineyards in Alto Monferrato (North-West Italy). Soil Tillage Res. 2016, 155, 176-189. [CrossRef]

11. Ramos, M.C.; Martínez-Casasnovas, J.A. Nutrient losses by runoff in vineyards of the Mediterranean Alt Penedès region (NE Spain). Agric. Ecosyst. Environ. 2006, 113, 356-363. [CrossRef]

12. Bienes, R.; Marques, M.J.; Ruíz-Colmenero, M. Cultivos herbáceos, viñedos y olivares. El manejo tradicional del suelo y sus consecuencias en la erosión hídrica. Cuadernos de Investigación Geográfica 2012, 38, 49-74. [CrossRef]

13. Gómez, J.A.; Llewellyn, C.; Basch, G.; Sutton, P.B.; Dyson, J.S.; Jones, C.A. The effects of cover crops and conventional tillage on soil and runoff loss in vineyards and olive groves in several Mediterranean countries. Soil Use Manag. 2011, 27, 502-514. [CrossRef]

14. Pipan, P.; Kokalj, Ž. Transformation of the Jeruzalem hills cultural landscape with modern vineyard terraces. Acta Geogr. Slov. 2017, 57, 149-162. [CrossRef]

15. Nearing, M.A.; Xie, Y.; Liu, B.; Ye, Y. Natural and anthropogenic rates of soil erosion. Int. Soil Water Conserv. Res. 2017, 5, 77-84. [CrossRef]

16. Verheijen, F.G.A.; Jones, R.J.A.; Rickson, R.J.; Smith, C.J. Tolerable versus actual soil erosion rates in Europe. Earth Sci. Rev. 2009, 94, 23-38. [CrossRef]

17. Corti, G.; Cavallo, E.; Cocco, S.; Biddoccu, M.; Brecciaroli, G.; Agnelli, A. Evaluation of erosion intensity and some of its consequences in vineyards from two hilly environments under a Mediterranean type of climate, Italy. In Soil Erosion in Agriculture; Godone, D., Stanchi, S., Eds.; Intech Open Access Publisher: London, UK, 2011; pp. 113-160.

18. Martínez-Casasnovas, J.A.; Ramos, M.C.; Ribes-Dasi, M. On-site effects of concentrated flow erosion in vineyard fields: Some economic implications. Catena 2005, 60, 129-146. [CrossRef]

19. Ruiz-Colmenero, M.; Bienes, R.; Eldridge, D.J.; Marques, M.J. Vegetation cover reduces erosion and enhances soil organic carbon in a vineyard in the central Spain. Catena 2013, 104, 153-160. [CrossRef]

20. Van Leeuwen, C.; Friant, P.; Choné, X.; Tregoat, O.; Koundouras, S.; Dubourdieu, D. Influence of climate, soil, and cultivar on terroir. Am. J. Enol. Vitic. 2004, 55, 207-217.

21. Pardini, A.; Faiello, C.; Longhi, F.; Mancuso, S.; Snowball, R. Cover crop species and their management in vineyards and olive groves. Adv. Hortic. Sci. 2002, 16, 225-234.

22. Ruiz-Colmenero, M.; Bienes, R.; Marques, M.J. Soil and water conservation dilemmas associated with the use of green cover in steep vineyards. Soil Tillage Res. 2011, 117, 211-223. [CrossRef]

23. Tesic, D.; Keller, M.; Hutton, R.J. Vineyard floor management practices-Influence of vineyard floor management practices on grapevine vegetative growth, yield, and fruit composition. Am. J. Enol. Vitic. 2007, 58, 1-11.

24. Mercenaro, L.; Nieddu, G.; Pulina, P.; Porqueddu, C. Sustainable management of an intercropped Mediterranean vineyard. Agric. Ecosyst. Environ. 2014, 192, 95-104. [CrossRef]

25. Sweet, R.M.; Schreiner, R.P. Alleyway cover crops have little influence on Pinot noir grapevines (Vitis vinifera L.) in two western Oregon vineyards. Am. J. Enol. Vitic. 2010, 61, 240-252.

26. Ferrero, A.; Usowicz, B.; Lipiec, J. Effects of tractor traffic on spatial variability of soil strength and water content in grass covered and cultivated sloping vineyard. Soil Tillage Res. 2005, 84, 127-138. [CrossRef]

27. Gómez, J.A. Sustainability using cover crops in Mediterranean tree crops, olives and vines—Challenges and current knowledge. Hung. Geogr. Bull. 2017, 66, 13-28. [CrossRef]

28. López-Vicente, M.; García-Ruiz, R.; Guzmán, G.; Vicente-Vicente, J.L.; Van Wesemael, B.; Gómez, J.A. Temporal stability and patterns of runoff and runon with different cover crops in an olive orchard (SW Andalusia, Spain). Catena 2016, 147, 125-137. [CrossRef]

29. Wu, G.-L.; Liu, Y.; Yang, Z.; Cui, Z.; Deng, L.; Chang, X.-F.; Shi, Z.-H. Root channels to indicate the increase in soil matrix water infiltration capacity of arid reclaimed mine soils. J. Hydrol. 2017, 546, 133-139. [CrossRef]

30. Catania, P.; Badalucco, L.; Laudicina, V.A.; Vallone, M. Effects of tilling methods on soil penetration resistance, organic carbon and water stable aggregates in a vineyard of semiarid Mediterranean environment. Environ. Earth Sci. 2018, 77, 348. [CrossRef]

31. Biddoccu, M.; Ferraris, S.; Pitacco, A.; Cavallo, E. Temporal variability of soil management effects on soil hydrological properties, runoff and erosion at the field scale in a hillslope vineyard, North-West Italy. Soil Tillage Res. 2017, 165, 46-58. [CrossRef] 
32. Marques, M.J.; García-Muñoz, S.; Muñoz-Organero, G.; Bienes, R. Soil conservation beneath grass cover in hillside vineyards under Mediterranean Climatic conditions (Madrid, Spain). Land Degrad. Dev. 2010, 21, 122-131. [CrossRef]

33. López-Vicente, M.; Álvarez, S. Stability and patterns of topsoil water content in rainfed vineyards, olive groves, and cereal fields under different soil and tillage conditions. Agric. Water Manag. 2018, 201, 167-176. [CrossRef]

34. García-Díaz, A.; Marqués, M.J.; Sastre, B.; Bienes, R. Labile and stable soil organic carbon and physical improvements using groundcovers in vineyards from central Spain. Sci. Total Environ. 2018, 621, 387-397. [CrossRef] [PubMed]

35. Celette, F.; Gaudin, R.; Gary, C. Spatial and temporal changes to the water regime of a Mediterranean vineyard due to the adoption of cover cropping. Eur. J. Agronomy 2008, 29, 153-162. [CrossRef]

36. Gaudin, R.; Celette, F.; Gary, C. Contribution of runoff to incomplete off season soil water refilling in a Mediterranean vineyard. Agric. Water Manag. 2010, 97, 1534-1540. [CrossRef]

37. Huang, M.; Gallichand, J.; Dong, C.; Wang, Z.; Shao, M. Use of soil moisture data and curve number method for estimating runoff in the Loess Plateau of China. Hydrol. Process. 2007, 21, 1471-1481. [CrossRef]

38. López-Vicente, M.; Navas, A. A new distributed rainfall-runoff (DR2) model based on soil saturation and runoff cumulative processes. Agric. Water Manag. 2012, 104, 128-141. [CrossRef]

39. Rodrigo-Comino, J.; Iserloh, T.; Lassu, T.; Cerdà, A.; Keestra, S.D.; Prosdocimi, M.; Brings, C.; Marzen, M.; Ramos, M.C.; Senciales, J.M.; et al. Quantitative comparison of initial soil erosion processes and runoff generation in Spanish and German vineyards. Sci. Total Environ. 2016, 565, 1165-1174. [CrossRef] [PubMed]

40. Ramos, M.C.; Martínez-Casasnovas, J.A. Soil loss and soil water content affected by land leveling in Penedès vineyards. Catena 2007, 71, 210-217. [CrossRef]

41. Gómez, J.A.; Vanwallenghem, T.; De Hoces, A.; Taguas, E.V. Hydrological and erosive response of a small catchement under olive cultivation in a vertic soil during a five-year period: Implications for sustainability. Agric. Ecosyst. Environ. 2014, 188, 229-244. [CrossRef]

42. Ramos, M.C.; Durán, B. Assessment of rainfall erosivity and its spatial and temporal variabilities: Case study of the Penedès area (NE Spain). Catena 2014, 123, 135-147. [CrossRef]

43. Cerdà, A.; González-Pelayo, Ó.; Giménez-Morera, A.; Jordán, A.; Pereira, P.; Novara, A.; Brevik, E.C.; Prosdocimi, M.; Mahmoodabadi, M.; Keesstra, S.; et al. Use of barley straw residues to avoid high erosion and runoff rates on persimmon plantations in Eastern Spain under low frequency-high magnitude simulated rainfall events. Soil Res. 2016, 54, 154-165. [CrossRef]

44. Badía-Villas, D.; Cuchí-Oterino, J.A.; Martí i Dalmau, C.; Casanova-Gascón, J. Los Suelos de los Viñedos de la Denominación de Origen Somontano; Prensas Universitarias de Zaragoza: Zaragoza, Spain, 2006.

45. López-Vicente, M.; Ben-Salem, N. Computing structural and functional flow and sediment connectivity with a new aggregated index: A case study in a large Mediterranean catchment. Sci. Total Environ.. under review.

46. López-Vicente, M.; Álvarez, S. Influence of DEM resolution on modelling hydrological connectivity in a complex agricultural catchment with woody crops. Earth Surf. Process. Landforms 2018, 43, 1403-1415. [CrossRef]

47. López-Vicente, M.; Navas, A. Routing runoff and soil particles in a distributed model with GIS: Implications for soil protection in mountain agricultural landscapes. Land Degrad. Dev. 2010, 21, 100-109. [CrossRef]

48. López-Vicente, M.; Quijano, L.; Palazón, L.; Gaspar, L.; Navas, A. Assessment of soil redistribution at catchment scale by coupling a soil erosion model and a sediment connectivity index (Central Spanish Pre-Pyrenees). Cuad. Investig. Geogr. 2015, 41, 127-147. [CrossRef]

49. De Oliveira, J.P.B.; Cecílio, R.A.; Pruski, F.F.; Zanetti, S.S.; Moreira, M.C. Assessing the use of rainfall synthetic series to estimate rainfall erosivity in Brazil. Catena 2018, 171, 327-336. [CrossRef]

50. Renard, K.G.; Foster, G.R.; Weesies, G.A.; McCool, D.K.; Yoder, D.C. Predicting Soil Erosion by Water: A Guide to Conservation Planning with the Revised Universal Soil Loss Equation (RUSLE); Handbook \#703; US Department of Agriculture: Washington, DC, USA, 1997.

51. Vachaud, G.; Passerat De Silans, A.; Balabanis, P.; Vauclin, M. Temporal stability of spatially measured soil water probability density function. Soil Sci. Soc. Am. J. 1985, 49, 822-828. [CrossRef]

52. López-Vicente, M.; Quijano, L.; Navas, A. Spatial patterns and stability of topsoil water content in a rainfed fallow cereal field and Calcisol-type soil. Agric. Water Manag. 2015, 161, 41-52. [CrossRef]

53. Ramos, M.C.; Jones, G.V.; Martínez-Casasnovas, J.A. Structure and trends in climate parameters affecting winegrape production in northeast Spain. Clim. Res. 2008, 38, 1-15. [CrossRef] 
54. Pare, N.; Andrieux, P.; Louchart, X.; Biarnes, A.; Voltz, M. Predicting the spatio-temporal dynamic of soil surface characteristics after tillage. Soil Tillage Res. 2011, 114, 135-145. [CrossRef]

55. Rodrigo-Comino, J.; Senciales, J.M.; Ramos, M.C.; Martínez-Casasnovas, J.A.; Lasanta, T.; Brevik, E.C.; Ries, J.B.; Ruiz-Sinoga, J.D. Understanding soil erosion processes in Mediterranean sloping vineyards (Montes de Málaga, Spain). Geoderma 2017, 296, 47-59. [CrossRef]

56. Smets, T.; López-Vicente, M.; Poesen, J. Impact of subsurface rock fragments on runoff and interrill soil loss from cultivated soils. Earth Surf. Process. Landforms 2011, 36, 1929-1937. [CrossRef]

57. Biddoccu, M.; Ferraris, S.; Cavallo, E.; Opsi, F.; Previati, M.; Canone, D. Hillslope Vineyard Rainfall-Runoff Measurements in Relation to Soil Infiltration and Water Content. Procedia Environ. Sci. 2013, 19, 351-360. [CrossRef]

(C) 2018 by the authors. Licensee MDPI, Basel, Switzerland. This article is an open access article distributed under the terms and conditions of the Creative Commons Attribution (CC BY) license (http:/ / creativecommons.org/licenses/by/4.0/). 